\title{
KNJIŽEVNOST NA RUBOVIMA RATA. ESEJSKA FAZA BORE ĆOSIĆA
}

\section{Miodrag Maticki}

\author{
UDK: 821.163.41-4Ćosić, B. \\ Izvorni znanstveni članak
}

\begin{abstract}
Sažetak: Slobodnije literarno osvetljavanje epohâ poratnog razvoja Jugoslavije koincidira s počecima kritičkog preispitivanja NOR-a i njegovih ideoloških i političkih posledica te razmišljanjima o mogućnostima sistemskih promena u društvu. Pisci se okreću žanrovski hibridnoj prozi, kombinujući dokumetarnost, stil dnevničkog slikanja događaja, sećanja, memoaristike, dijaloške naracije tipa „ljudi govore” - sve to podređeno esejističkim imperativima. Ratni raspad Jugoslavije 1990-ih još više pospešuje cvetanje proze u znaku prepletenih hibridnih žanrova - sećanja, memoara, dnevnika i eseja. U srpskoj književnosti pritom se izdvajaju autori koji u ratnim ili poratnim godinama postaju apatridi. Njima posebno pogoduju hibridni žanrovi i stvaralačke slobode koje takvi žanrovi pružaju. Pišući na rubovima rata, iz godine u godinu sve udaljeniji od stvarnosti u Srbiji, razlikuju se i po sve nesigurnijem određivanju svoje naratorske pozicije pa i postepenom napuštanju početnih postulata i motiva opredeljivanja za apatridstvo. Reč je pre svega o Bori Ćosiću, Mirku Kovaču, Aleksandru Tišmi, Vidosavu Stevanoviću, Arseniju Jovanoviću itd. Ovaj članak problemski se fokusira na Ćosićevo esejsko stvaralaštvo „na rubovima rata”.
\end{abstract}

Ključne reči: totalitarizam, samoizgnanstvo, apatridnost, esej, književnost na rubovima rata, Bora Ćosić

[?

godinama kada su narodi Jugoslavije, intelektualna elita, počeli da razmišljaju o jasnijem određivanju prema narodnooslobodilačkom ratu i njegovim ideološkim posledicama, o promenama i države i sistema, započelo je i u literaturi slobodnije osvetljavanje pojedinih epoha poratnog razdoblja, da pomenem tek talas romana i svedočanstvene proze o Golom otoku ili pak političko-satirični teatar poput onog u Beogradu na Zvezdari. Povedeni Krležinim naknadnim dnevnikom, znamenitiji pisci okrenuli su se žanrovski hibridnoj prozi, kombinujući dokumentarnost, stil dnevničkog slikanja događaja, sećanja, memoaristike, pa i esejističkog promišljanja kada je reč o pojmu ketman ${ }^{1}$ (uvek

Ketman je termin koji opstojava u literaturi, a koristi ga i obrazlaže Predrag Palavestera. V. Predrag PALAVESTRA, Nekropolje, Beograd 2004. Rat vođen na prostorima bivše Jugoslavije odredio je svojevrstan angažman pisaca iz Srbije. Nespremni da se, bez odgovarajuće distance, u svojim delima prihvate opisivanja istorijskih događaja koji su bili u toku (mada je bilo brzopletih pisaca koji su mahom stvarali neubedljiva i propagandna dela), oni se okreću 
su u tom kontekstu pisali o drugima), često zaboravljajući na lični doprinos ovome fenomenu. Takva se proza rado čitala, bila je zastupljena u feljtonistici, uporedo je cvetala sa prozom romansirane istorije, u boljem slučaju sa istorijskim romanom. U tom kontekstu važno mesto zauzela je posebna vrsta „ratne literature” koju Kejt Maklohlin određuje kao „diskurs vremenskih i prostornih granica rata”. ${ }^{2}$ Reprezentacija rata u takvim tekstovima ograničava se na periferiju oružanog sukoba, gde se odvijaju njegove pripreme i reflektuju njegove posledice. Ta granična zona predstavlja i tradicionalno žensko područje budući da se nalazi izvan sfere neposrednog borbenog iskustva, što dolazi do izražaja u književnosti koja nastaje na rubovima rata. ${ }^{3}$

Institut za književnost i umetnost iz Beograda, u saradnji sa Institutom za književnost iz Sarajeva i kolegama iz Hrvatske, nimalo slučajno održao je 1991. godine naučni skup o istorijskom romanu, a štampani zbornik pod istim naslovom objavljen je u Tuzli 1992. Međutim, rat vođen na tim prostorima učinio da se tiraž uništi. Početkom 1996, supruga sekretara Instituta iz Sarajeva Fahre Trtka donela je i predala mi, kao uredniku zbornika, sačuvan rukopis spreman za štampu. Zbornik je objavljen te godine i nosi - što je jedinstveni slučaj - dve godine izdanja: 1992. i $1996 .{ }^{4}$

Ratovi u kojima se raspala Jugoslavija pospešili su još u većoj meri cvetanje proze pisane u znaku prepletenih hibridnih žanrova - sećanja, memoara, dnevnika, „istorijske metaproze”, jednom rečju i najpre eseja, koji postaje „svojevrstan dijalog sa prošlošću u svetlu sadašnjosti". ${ }^{5}$ Autori koji su svojim delima želeli da se odrede prema događajima koje je prouzrokovao Drugi svetski rat krenuli su sa nizom knjiga u kojima su, sa naknadnom pameću, pokušavali da sagledaju svoje učešće u sudbonosnim zbivanjima tokom i posle Drugog svetskog rata (više romana i desetak knjiga sećanja Dobrice Ćosića) ili da izlože svoje kritičko viđenje propadanja tekovina građanskog društva posle Drugog svetskog rata (višeknjižje Efemeris i niz knjiga sećanja Dejana Medakovića koje nastavljaju da izlaze i posle njegove smrti), a svakako treba izdvojiti i dnevnike sa izrazito književnim aspiracijama, poput onih Aleksandra Tišme: Dnevnik koji obuhvata period od 1942. do 1951, objavljen 1991, i onaj objavljen dve godine pre njegove smrti, 2001. No, kada je reč o srpskoj književnosti, to su mahom bili autori koji pišu u matici želeći da sebi odrede mesto u zbivanjima koje opisuju i kritički ih sagledaju, dobrim delom suprotstavljajući se pristupima kritičara koji, verni principima odanosti dnevnoj politici, po ko zna koji put bivaju spremni da žrtvuju pisca radi njegovih političkih nazora ili postupaka koji nemaju uvek direktne veze sa literaturom.

Po tonu i načinu pisanja, po angažmanu proze, ovi su autori slični autorima koji su tokom ratova vođenih na Balkanu u poslednjoj deceniji 20. veka postajali apatridi, koji su niz

esejizmu i memoaristici, preispitujući svoj odnos prema vladajućoj ideologiji posle Drugog svetskog rata. Sve vreme teže da izmene sliku svoje biografije. Poslušnici su nastojali da pokažu kako su iz jednoumlja sazreli u demokratskom smislu do nivoa kulturnih desidenata, a drugi, u mladosti vaspitavani u građanskom duhu, doživljavaju dvostruko preokretanje svog karaktera. Od ketmana koji se preokreću i pristaju uz program vladajuće ideologije, sa nastupanjem demokratskih promena u kulturi i književnosti pokušavaju iznova da se uključe u prve redove demokratskog društva.

2 Kate McLOUGHLIN, Authoring War. The Literary Representation of War from the Iliad to Iraq, Cambridge 2011., 140.

3 Vladislava RIBNIKAR, „Obnova istorijskog romana: Poslednji zanosi MSS Milice Mićić Dimovske”, Književna istorija, 44/2012., br. 147, 429.-454. Ovde 439 .

Miodrag MATICKI (ur.), Istorijski roman: zbornik radova, Beograd - Sarajevo, 1992. i 1996.

Linda HUTCHEON, A Poetics of Postmodernism, New York - London 1988., 19. 
godina dok je rat trajao, pa dok su trajale ili još traju njegove posledice, izbivali iz Srbije. Kako su oni pisali na rubovima rata, iz godine u godinu sve udaljeniji od stvarnih događaja i zbivanja u matici, oni se i razlikuju po sve nesigurnijem određivanju svoje naratorske pozicije, po postepenom napuštanju postulata koji su bili početni njihov credo i motiv opredeljivanja za apatridstvo. Njima posebno pogoduju hibridni žanrovi i stvaralačke slobode koje takvi žanrovi pružaju. $\mathrm{U}$ istom periodu cveta i istorijski roman pisan bez distance, često dogmatski ustrojen - najneuspeliji kada ga pišu oni sa rubova rata, a ne oni koji su direktno rat doživljavali. Tako se u tim romanima, bez obzira sa koje strane potiče autor, javlja isti tip dobrovoljca, ponavljaju se stajaće scene i sve, najzad, liči na "fabrikovane” romane o Golom otoku, u kojima su se ponavljale klišetirane scene mučenja logoraša. „Doživljavanje" u ovim delima bilo je praćeno gotovo degutantnom patetikom, pogotovu kada su autori romana o Golom otoku ljudi rođeni posle ukidanja zloglasnog logora.

Slika zbivanja u poslednjoj deceniji 20. veka u najvećoj meri, pak, građena je književnim delima i filmovima s tezom, čije se dejstvo okončava jednokratnom upotrebom. Za kulturološki pristup literaturi daleko je zanimljivija proza koja je u znaku sažimanja hibridnih žanrova - sećanja, dnevnika, memoara, hronika i eseja. Pisanja takvih knjiga latili su se gotovo svi značajniji autori koji su rat posmatrali sa distance, u čijim je delima oslikan zanimljiv svet emigranata: njihova okupljanja, njihova glad za informacijama, njihovo stalno tumaranje Evropom po kružnici omeđenoj rubovima rata. Ovaj tip proze posebno je oživeo posle 2001, kada su autori osetili potrebu da se vrate i iznova uključe u književne tokove svoje nekadašnje matice, smatrajući da samo knjigom mogu da objasne sebe, svoj postupak kritičkog sagledavanja onoga što se zbivalo u matici, svoje apatridstvo. Dobrim delom, počev od pravdanja svog odnosa prema jeziku (u početku među piscima samoizgnanicima vladala je floskula da jezik nije važan za pisca, da je njihova domovina tamo gde žive), oni pokušavaju da objasne i potonje promene svojih stavova, pre svega o jeziku - polako napuštaju silovanje sopstvenog jezika kako bi se uključili u književnost novog okružja, menjaju svoj pristup ocenama istorijskih zbivanja i iskazuju težnju da se iznova povrate matici i književnim tokovima matice kojima su nekada pripadali. Težište svoje kritike oni sad sve više prebacuju na ideološki posuvraćen sistem jednopartijske države, zaboravljajući da su, do rata devedesetih godina 20. veka, u tom sistemu zauzimali značajne pozicije u Partiji i kulturnim institucijama, da je taj sistem pri kraju bio dosta benigan, da su mnogi tadašnji izvikani „disidenti” objavili više knjiga u tom vremenu nego posle 2001. godine.

Vremenom, sa distance, sve jasniji postaje prvotni period jednoumlja, period 1939-1947. godina. Slobodnije se izjašnjavaju oni koji su bili deo tog jednoumlja, čak i pisci članovi Politbiroa. Prilika je da, danas, pokažu da su i tada, u ideološkoj teskobi imali razuma i hrabrosti da vuku razložne poteze, da zaštite, učine usluge progonjenim kolegama, da podrže modernije usmerena periodična glasila. I oni koji su bili pripadnici najvišeg sloja predratne građanske klase - pogotovu oni koji su želeli da iz oportunizma pristupe Komunističkoj partiji pa su mahom bili odbijeni (možda je i to razlog što su njihove naknadne kritike nestalog poretka toliko žestoke) - nastojali su da mitologiziraju i najmanje tačke kulturološkog otpora, da prenaglašavaju krugove pisaca i intelektualaca koji su „mislili nešto drugačije”, poput pisaca i kulturnjaka iz Simine ulice ili umetnika koji su se bavili modernom likovnom izražajnošću, poput stanovnika zgrade br. 19 na Kosančićevom ven$\mathrm{cu}$ u kojoj je nastao pokret Medijala. Oni naprosto grade sliku kakvi bi želeli da su bili. O tim kružocima postoje posebne knjige sećanja, na primer, knjige Dejana Medakovića, Borislava Mihajlovića Mihiza, Arsenija Jovanovića. Sećanjima i memoarskim knjigama, 
delom pisanim i kao „naknadni alibi”, oni pokušavaju da iz književno-kulturološkog ugla utvrde sliku koja rediguje krajnje negativnu, kapitulantsku predstavu tih oštrih, tvrdih godina. Nasuprot njima, Vasko Popa, u skladu sa sukobom na levici, ispevao je 1950. godine pesmu o slavuju koji ne dozvoljava da bude upregnut u zahuktala kola poetike socrealizma.

I samoizgnanici iz ratnih godina s kraja 20. veka, najpre, pišu o otklonu od Srbije i razlozima svog odlaska. Njihovi iskazi će biti polako ublažavani, u odnosu na prvotne, poput onih Bore Ćosića po prispeću u Berlin da je u Beogradu umro, a u Berlinu iznova rođen. Ali, što se sve više problematizuje pitanje njihova (ne)povratka, oni se sve više obrušavaju na britke godine uspostavljanja političkog jednoumlja, jednopartijske Jugoslavije, na period do 1947. godine. U tom periodu nalaze korene zla i devijantnih preusmeravanja kolektivne svesti. Najpre, u ljudima koji su upravo tada stasavali i bili delatni, nalaze razlog što su mnogi od njih i krajem 20. veka, okrećući se nacionalizmu, novoj ideji koja je po zakonomernosti jednoumlja izbacivala prečesto parolu „Nema alternative!”, i počela iznova da svoje postupke podupire svepravdajućom floskulom „U ime naroda!” Njima, kada je reč o delovanju intelektualaca u epohama totalitarizma, Đerđ Lukač iznova postaje tema i nameće im se kao paradigmatičan ideolog delatnik, nastoje da fenomen Lukač objasne uz pomoć paralela sa ličnostima koje su pred Drugi svetski rat i posle rata izabrali samoizgnanstvo kao neizbežni put za ostvarivanje ličnih, stvaralačkih sloboda (Tomas Man, Miloš Crnjanski). I kada pišu o ratu vođenom krajem 20. veka oni projektuju i osuđuju mehanizam jednoumlja epohe 1939-1947, osuđujući ga na isti način. U žiži njihovih interesovanja se, tako, našla i čarobna i poletna parola „U ime naroda”, reinkarnirana u aktuelnom političkom delovanju krajem 20. veka parolom, opasnom retoričkom poštapalicom „Svi!”, dok je njihovo jednoumlje vazda podupirano neizmenjenom sintagmom „Nema alternative!” Ta isključivost nacionalističkog neosocijalizma našla je snažnu potporu u modelu kulturološkog i socijalističkog ponašanja u ratnim i poratnim godinama do 1947, u periodu prejasnih ciljeva i pregnuća, bilo da je reč o obnovi, iskorenjivanju buržoazije, nalaženju narodnih neprijatelja spolja i iznutra.

Pisci na rubovima rata trude se da istaknu tu simetriju, ponavljanje kulturološkog modela, i zato se obrušavaju na rani period ideološki unificiranog kolektivnog ponašanja, zaboravljajući da su, dakako metaforički rečeno, i sami nosili štafetu ili se bar trudili da ne budu zaobiđeni kao njeni nosioci, glavni učesnici u tom socijalističkom folklornom obredu posvećenom kultu ličnosti.

Kada je reč o (ne)povratku apatrida u njihovim esejističkim proznim delima nastalim na razmeđu vekova, zahvaljujući hibridnosti i mešanju žanrova, sve više prostora zauzimaju esejistička iskakanja iz sadašnjeg u prošlo vreme, pa i obratno, u njihovim novijim knjigama sve se više okreću ranijem periodu jednoumlja tako da je sve bleđa njegova simetrija sa epohom sa kraja 20. veka u kojoj je prenaglašeni nacionalizam bio paradigmatsko obeležje opozitno proporcionalno u odnosu na epohu 1939-1947, kada je nacionalizam korenito potiran. Tim zaokretom oni opet kreću ketmanskom linijom, u obratnom smeru, pogotovu što je sasvim sazrelo vreme da se kritički preispita period do 1947. godine. Puno toga je, danas, nesporno i za većinu kolektiva pojedinih naciona bivše Jugoslavije. Danas je preovlađujuća svest da jednoumlje nije mnogo dobra donelo niti može doneti, ali je prisutno i otrežnjavajuće saznanje da je u oba slučaja, u obe epohe, tolika većina kolektiva bila spremna da veruje u petoljetke, u samoupravljanje, u isključive nacionalističke ideje s kraja 20. veka. Zato ima smisla pristup koji omogućuje da se čuje i glas ne samo istoričara, već i kulturologa u najširem smislu, pa i izučavaoca istorije književnosti. Jer, pisci i njihova 
dela jesu svojevrstan kulturološki barometar, pisci su, često, laste koje mogu nagovestiti i proleće, poput pomenute pesme Vaska Pope o slobodi stvaralaštva, tumačenoj kao programski opozit socrealizmu, ali mogu da nagoveste i mraz koji je svojevremeno stizao iz Kremlja, najlepše izražen u pripevu koračnice Vladimira Majakovskog: „Ko gazi desnom? Leva! Leva! Leva!”

Uvođenje uloge kolektiva u tumačenje totalitarizma svakako proširuje ovaj pojam, bitan kada je reč o epohi 1939-1947. Totalitarizam, uprošćeno, možemo da odredimo i kao spremnost na represiju prema drugima da bi se ostvarila opsesivna ili aksiomatično prihvaćena ideja o promeni svesti društva i sveta u celini. Naime, nije samo reč o nosiocima totalitarizma, o onima koji imaju moć (koji su tu moć zadobili) da čine, koji vode politiku, o zidarima jednoumlja, već i o većini društva koja to prihvata bespogovorno kao nešto što je nužno, što se čini za narod, za zaštitu domovine od spoljnih i unutrašnjih neprijatelja, za dobro društva u celini, za globalizaciju, što je jedino vredno i moguće. Bez tog utemeljenja kojem i mase pojedinih naroda doprinose, totalitarizam ne bi bio toliko rigidan i u svojoj najžešćoj fazi toliko prek i isključiv. Totalitarizam se u prvoj fazi postavlja kao veliki projekat bez premca, čiji su ciljevi dalekosežni. Treba istaći da, potom, on stalno traži nove ideološke nadopune, pristaje i na ustupke da bi istrajao po svaku cenu, ali upravo te faze njegove transformacije neminovno postaju i faze njegovog postupnog urušavanja. Tako je u svojim osvajačkim pohodima prošao i Aleksandar Makedonski koji je mačem krenuo da uvećava svoju državu, ali ubeđen da je to jedini put i da proširi tada vodeću kulturu stare Grčke. Tako je nastupao i Napoleon, i odista su njegova osvajanja ostavila duboke i značajne kulturološke tragove čak i na našem terenu. Nastupajući fašizam bio je ubeđen da će, u budućnosti, ostvariti nešto veliko, u svetskim razmerama povezano i organizovano (šta bi činio Gebels da je raspolagao današnjom komunikacijskom silom!), za šta vredi i dati živote i prihvatiti žrtve, bolje reći žrtvovati druge. I danas su preglasne ideje o promenama uređenja i tradicija pojedinih naroda, o tome kako (čak i upotrebom vojne sile) vladajuće sisteme i nazore nametnuti drugima, objediniti velike prostore idejom „za koju se vredi boriti po svaku cenu". Kada je reč o Evropi, sve je to u krajnjoj suprotnosti sa širenjem evropeizacije, posebno u epohi prosvećenosti, kada su u visokom stepenu cenjene različitosti naroda, kada su ciljevi bili otkrivanje ličnih sloboda, stvaranje slobodnog Evropejca koji neće više robovati dogmama i činiti ono što mu je vekovima nametano, počev od crkvenih nazora ponašanja i življenja, pa do okoštalih normi građanskog društva.

$\mathrm{Na}$ ovom planu razvijaju se i dinamično menjaju esejistička prozna promišljanja pisaca koji stvaraju i u matici ali i na rubovima rata, u apatridstvu, dakako idući drugim smerom. Oni traže paralele koje se iz perioda 1939-1947. projektuju u epohi na razmeđi 20. i 21. veka. Velika ideja kao osnova neototalitarizma bila je nacija, radikalno utvrđivanje i obnova država na ovim prostorima. U ideološkim pristupima i najvećih literarnih imena zagovaralo se totalno rešenje, čak se i licitira sa brojem žrtava koje vredi podneti da bi se jednom, za svagda, rešilo nacionalno pitanje. U uvodnom izlaganju na jednoj takvoj skupštini pisaca, neposredno pre početka ratnih sukoba, na primer, uvodničar, inače veliki pisac, tridesetak je puta upotrebio reč radikalno u trenutku kada još ni na pomolu nije bilo osnivanje Radikalne partije. ${ }^{6}$ Malobrojna neslaganja sa takvim pristupima, čak i na zvaničnim skupštinama pisaca, bila su, tada, beznačajna, pogotovu što su većinom dolazila od strane komunistički opredeljenih pisaca, koji nisu mogli da shvate da te partije, kao zaštitnog

Reč je o Radikalnoj partiji osnovanoj u Srbiji krajem 20. veka. 
znaka jednopartijske južnoslovenske države u suštini odavno nije bilo. U tom kontekstu treba razumevati postupke pisaca koji su bili sve spremniji da se opredele za samoizgnanstvo i apatridstvo, da se iznova u svom stvaralaštvu okrenu epohi totalitarizma iz perioda 1939-1947, da, možda, i prenaglašeno nalaze njen direktni odraz u političkoj sadašnjosti sredine iz koje potiču. Za takvo opredeljenje presudni su bili: žestoka medijska propaganda i nespremnost da se podnese prozivka, najčešće minornih pisaca koji su izišli iz senke anonimnosti ubeđeni da je došao njihov trenutak. Čak je unapred bilo osuđivano i njihovo apatridstvo: „Onaj ko danas bježi iz srpskog roda je izdajnik!”, ističe se u Mihovićevoj knjizi Rat su započeli mrtvi objavljenoj 1993. godine.'

Važno je istaći da među piscima koji su slobodu svog stvaralaštva potražili u samoizabranom apatridstvu, samoizgnanstvu, nalazimo značajna imena srpske literature čija dela, a pogotovu paradigmatske odlike epohe koju čine dve decenije na razmeđi vekova, ne mogu biti izučavani valjano ako se zaobiđe njihova proza pisana hibridnim žanrovima o kojima je reč. Da pomenem dela Bore Ćosića, Mirka Kovača, Aleksandra Tišmu, Vidosava Stevanovića, Arsenija Jovanovića. Svima njima na raspolaganju je svakako bilo delo Milana Kundere, niz njegovih romana (ciklus: Smešne ljubavi, Knjiga smeha i zaborava, Nepodnošljiva lakoća postojanja, te Neznanje iz 2000. godine), u kojima se egzil predstavlja kao veoma važna pojava 20 . veka. Kundera posebno ističe magičnu temu velikog povratka u rodnu zemlju, uz naglašenu sumnju da posle dvadeset godina egzila povratak nije moguć, jer je egzilant rezultat dekonstrukcije i konstrukcije i opire se svakom ograničenju. To jeste pitanje ne puke nostalgije i bola savremenog egzila, već gubljenja i (ne)nalaženja identiteta. ${ }^{8}$ Za Edvarda Saida književnost egzila zauzela je mesto kao topos ljudskog iskustva, u nizu sa književnošću o avanturama, obrazovanjima i otkrićima. Said razlikuje pojmove izgnanik, izbeglica, iseljenik, emigrant. ${ }^{9}$ Vera Linhartova se na konferenciji u Francuskom institutu u Pragu 1993. godine posebno pozabavila „oslobodilačkim egzilom”, razlikujući prinudni od dobrovoljnog egzila, koji može biti bekstvo od okolnosti koje predstavljaju opasnost, tako i dobrovoljni odlazak u drugu, bolju sredinu, što podrazumeva nepripadanje, apatridnost, kao vid slobode. ${ }^{10}$

Delo Bore Ćosića Pogled maloumnog ${ }^{11}$ izdvajam zbog junaka ovog hibridnog dela. S jedne strane, Ćosić piše o Tomasu Manu, o njegovoj sudbini izgnanika i pisca, a s druge, o Đerđu Lukaču, misliocu „u dosluhu sa zlom”, koji ga podseća na Manovog Feliksa Krula. U tom esejističkom prostoru Ćosić teži da objasni sebe, svoje godine apatridstva, da iznađe smisao radikalnih postupaka kada je reč o slobodi stvaralaštva. Pored ovoga dela, ne mogu se zaobići još neka dela Bore Ćosića sa temom apatridstva i velikog (ne)povratka. To su roman Put na Aljaskü ${ }^{12}$ i Doručak kod Mažestika. Jedna paralelna povest. ${ }^{13}$

\footnotetext{
Dragan MIHOVIĆ, Rat su započeli mrtvi, Beograd 1993., 68.

8 Katarina V. MELIĆ, „Egzil ili veliki povratak u romanu Neznanje Milana Kundere”, Književna istorija, 44/2012., br. $147,413 .-428$.

9 Edvard SAID, „Razmišljanja o izgnanstvu”, Polja, br. 352, 28.-37. Ovde 33.

10 Vera LINHARTOVA, „Pour une ontologie dr l'exil” (http://www.france.czIMG/pdf).

11 Bora ĆOSIĆ, Pogled maloumnog, Zagreb 2001.

12 Bora ĆOSIĆ, Put na Aljasku, Beograd 2006.

13 Bora ĆOSIĆ, Doručak kod Majestica. Jedna paralelna povest, Beograd 2011.
} 
Posebno je zanimljiva njegova knjiga proze, po autorovom određenju hronika Konzul $u$ Beogradu. ${ }^{14}$ Imajući kao reper Embahade Miloša Crnjanskog, Ćosić u uvodnoj belešci pokušava da direktnije odredi svoje apatridstvo:

Nikada nisam radio u diplomatiji. Prema tome nisam u stanju da napišem jedne nove Embahade. Pa ipak, kako već dugo živim izvan zemlje, ja o svojoj bivšoj domovini razmišljam kao o udaljenom kraju gde sam službovao dosta dugo, a opet, kako ispada, za tu zemlju ostao sam stranac. Ovo su, dakle, moja sećanja, uspomene jednog stranca koji u sopstvenoj zemlji kao tuđinac boravio je. Otuda lica koja će se ovde pojaviti, iako stvarna, mogu delovati kao lutke u panoptikumu i kao marionete jednog teatra davnih događaja u Evropi. Kao kada ostareli diplomat reprodukuje svoje susrete s kojekakvim junacima povijesti, dejstvujućim licima jedne komedije, istorijske. Većinom, ovi ljudi su mrtvi, ostali, koliko ih je još na životu, mene mrtvacem smatraju. Tako počinje moja hronika, moje Embahade običnog sveta, beogradskog, u godinama između 1937. i završne sezone moga života onde, na početku raspada carevine Jugoslavije, socijalističke, početkom devedesetih. ${ }^{15}$

Na poslednjoj stranici ove hronike nastale na rubovima rata Ćosić evocira trenutak svog odlaska u apatridstvo. Zbivanja oko Vukovara, bacanje cveća na tenkove koji kreću na Vukovar, nacionalizmom uskovitlana svetina u Beogradu, vazda lepom gradu na Dunavu, koji je i u tursko doba s pravom nazivan „šeher Beograd”, učiniše da iz Beograda Ćosić bude ispraćen kao „beogradski konzul” na ,jedno lično putešestvije bez povratka”, da ode neopaženo ,iz one zgrade koja činila je pedeset pet godina (njegovog) života”. ${ }^{16}$

Putopisno-memoarska knjiga Put na Aljasku pokušaj je uspostavljanja ravnoteže, ispitivanja (ne)mogućnosti prihvatanja stare sredine iznova, možda eventualnog povratka. Ona jeste roman o povratku, pokušaj da se kroz sećanja i razgovore sa davnim prijateljima iznova sastavi mozaik preskočenog vremena. Ćosić je svestan velike praznine koja nalikuje prizoru praznog i žalosnog izloga te da punu prazninu, ali i moguću njenu ispunjenost, može da pruži samo daleki sever, beo i neutralan do bola. Zato svoj povratak preko Austrije i Beča (koju mu se u ovom kontekstu iznova ukazuju kao „staklena bašta”) Sloveniji, Hrvatskoj, Bosni, Srbiji, Beogradu, on sagledava kao putovanje na Aljasku. I ovo delo započinje određivanjem, alibijem ličnog apatridstva:

Da se čovek rodi ovde ili onde, stvar je slučajna. Time gubi se neka posebna vrednost termina domovina ili otadžbina: sve se svodi na geografske koordinate, profane tačke na mapi naše sudbine. Pa kada danas, posle više godina polazim na put u zemlju svoga rođenja, imam osećaj kao kada bih kretao u Afriku ili na Aljasku. Tako polazim u nepoznati kraj svoje prošlosti, a da zapravo ne znam zašto. ${ }^{17}$

Tu bi se, odmah, ovo delo i završilo da je sve to tako. Srećom, nije. Iako ističe da taj narativni put prelazi bez ikakve zamisli, političke ili ideološke, Ćosić prećutkuje motiv koji donosi poriv vrsnog pripovedača. I već u sledećoj rečenici izvija metaforu koja će se, kao pripev, ponavljati na sledećim stranicama: „Tako krećemo na Aljasku svog ranijeg života (podvukao M. M.), oslobođeni svega, čisti turisti na putu svoga bivstva, hodočasnici u zemlju onoga što smo već doživeli, davno."18

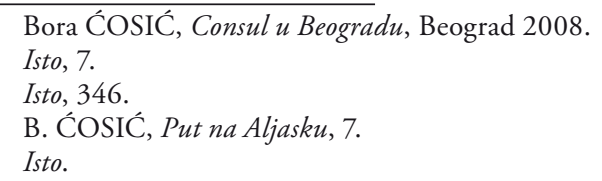


U knjizi Doručak kod Mažestika Ćosić nastoji da zumira zgusnuti kulturološki prostor Beograda, ne onaj populistički potez „od Slavije do Kalemegdana”, već kvart koji zahvata Obilićev venac, Knez Mihailovu ulicu, Dositejevu, Dobračinu, Strahinjića Bana, Knjižaru Gece Kona i Operu, u kojem se - kako se svima nama činilo i danas nam se čini, kako je to i Tomasu Manu izgledalo (i ovde Ćosić priziva Mana) - „odigrava nešto čega nigde drugde nema, gde posebne regule vladaju, i skoro zakoni, osobeni”, ${ }^{19}$ koji se na svojstven način decenijama i vekovima opire prolaznosti i čini „konstantu gradskog trajanja”. ${ }^{20} \mathrm{~A}$ oko kamere, oko naratora, kreće sa prozora sobe u Hotelu „Mažestik”, u koju je Ćosić na početku zakoračio kao u „novouspostavljenu postojbinu”. ${ }^{21}$ I kroz taj prozor počinje da se odvija film „sniman” svojevrsnom prozom u kojoj autor, kroz sećanja pokušava da fiksira proteklo, preskočeno vreme, da za trenutak vrati iz prošlosti sve one koji su u „Mažestiku” doručkovali i pili kafu uz razgovor, i Miloša Crnjanskog, Dušana Matića, ne bi li otkrio ono što određuje pojam „beogradsko”.

Recenzent knjige Pogled maloumnog, Jagna Pogačnik, ispratila je ovo delo Bore Ćosića kao „intelektualnu rekapitulaciju” autora koji „može recepirati fragmente poluzapamćenog, neshvatljivog, nepovezane odlomke i prolazne pojave", u kojoj su

(...) točke odmorišta i „nervozišta” rasute u rasponu od Frojdove psihoanalize i Beča s početka stoleća, preko Krleže, Lakana, Musila, sve do dadaista i ljute dadaističke crte, ironičnog slaganja sa zlom kao oblika opiranja, primjetne u slovenske grupe Lajbah (Laibach). Te krhotine, trenutni bljeskovi i asocijacije, spajaju se u umješno napisano štivo koje svjedoči o erudiciji, intelektualnoj zabrinutosti jednog Europljanina i humanista par excellence, skepsi, kao i vještom povezivanju dokumentarističke i beletrističke građe. ${ }^{22}$

Ćosić ovo svoje delo piše 1993. godine i ovako iskazuje razlog njegova nastanka:

Ovo govorimo pred jedan egzodus, pri silama mraka koje naplavljuju, i kada doista moramo se upitati (...) što ćemo, kuda ćemo i od čega ćemo? Pa ipak, i u toj tmuši u kojoj posejali smo prijatelje po različitim zemljama, omraženim, oklevetanim, adoriranim, neznatnim, nepostojećim, nepriznatim, preterano priznatim, ambivalentnim (...). ${ }^{23}$

U tolikoj zimi svog nezadovoljstva on živi od lektire, seća se vampira Save Savanovića, kermesa govorenja iz knjige Ljudi govore Rastka Petrovića, priziva Prusta kako bi otkrio logiku sopstvenog sećanja.

Ovu Ćosićevu knjigu čine tri poveće esejističke celine: Jedan evropski neurotik, Bečki slavljenik i Nakrivo, neuspjelo, popišano, kao i pogovor - Topografski post-scriptum. U prvom je junak esejističke proze Đerđ Lukač, mozak „komune”. Ćosića zanima njegov esejizam, ne on sam, već „dramatizacija eseja”, ${ }^{24}$ što se u njemu pojavljuju ličnosti kao u svakoj drugoj „umetničkoj” radnji, što je on romansijerski, beletristički. Čitav Lukačev esejistički „prepi-

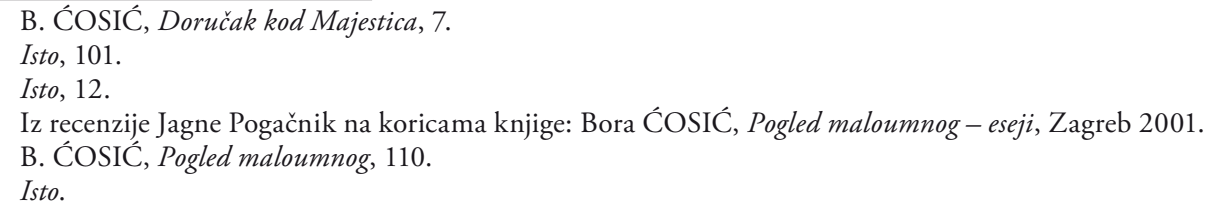


sivački” dar, posebno izražen u prvom „razdoblju eseja”, iz perioda Duše i oblika (prvotni firentinski estetizam), te onaj iz faze etičkog esejizma, kada se ispoljava Lukačeva vera u prevratničku snagu proletarijata, pa onaj religiozni, kada je Lukač bespogovorno verovao revoluciji, Ćosić vidi kao substituciju „pesničkog prepisivanja”, da umesto prepisivanja sa života Lukač „prepisuje sa knjiga, uvek različito napisanih”. ${ }^{25}$ Ćosić ističe da esej govori o nečemu već uobličenom, da se njime, „esejskom istinom”, samo iznova sređuje nešto što je već bilo, „da u svakom prosuđivanju, bilo ono svakodnevno, beletrističko ili filosofsko, ima nečega od esejstva, od esejizma”. ${ }^{26}$ Esej koristi „jedan posrednički, posredan i rekonstruktivni uvid o 'nečemu već bilom'”. 27

Idući za Lukačem i Poperom, Ćosić ide i dalje: „Sve je već bilo, ali da bilo bi uopšte, ono mora biti na jedan drugi način nego što bilo jeste, i to drugo ili novo jedina je potvrda da je ono prvo i staro uopšte moglo da se dogodi." ${ }^{28}$ I dodaje da se sve šta se odista događa, događa na vrhuncima. Sve ovo šlagvort je za autoalibi o samoizgnanstvu, oslonac za zaključak da se „istinske važne stvari zbivaju u samoći” ${ }^{29}$ koju može da najpotpunije omogući egzil, pozicija stvaraoca na Pontu. Sledi priča o tom novostvorenom, pogodnom prostoru samoizgnanstva, o vezi Lukača i Mana, iako su se sreli samo jednom, 1919. godine, iako je Man kao Kastorp samo klimao glavom dok je Lukač govorio, ali je posle uveo Lukača u roman Čarobni breg u liku Lea Nafte (Leo Naphta).

U Lukačevom esejskom periodu, u odrazu njegovog lika u Čarobnom bregu, Ćosić prepoznaje ne samo snažno izražen žanrovski oblik, već i „inaguraciju jednog esejističkog načina života”, ${ }^{30}$ ističe da je Lukač govorio svojim „životnim esejizmom”. ${ }^{31}$ Cosić izdvaja s razlogom Naftinu jezuitsku prirodu, svestan da kroz Naftu govori Niče („,biti čovek znači biti bolestan”32): „Nafta je govorio oštro i apodiktički, iako je on bio taj koji je branio širu slobodu." 33

U Pogledu maloumnog Ćosić meša vremena i svoj esej uskovitlava na postmodernistički način, pokušava da sebe odredi u vremenu i prostoru. Poruke koje su deo esejističkog autoalibija jesu one kada piše o „slobodnozidarskoj začahurenosti”, kada ističe da pripada Slaviji, kada insistira da pripada Hrvatskoj, da mu je baka iz Slavonije, da je rođen u Zagrebu, da je kolumnista Feral tribjuna, kada u završnom eseju Topografski post-scriptum pokušava da odredi svoj Pont: Rovinj, Venecija, Pula, Berlin, Beč.

Ćosić više stranica posvećuje žanrovskom određenju eseja. Kada je reč o literaturi, svestan je da esej, kao proza individue, neprekidno trpi upliv tuđih uticaja, počev od raznih oblika naracije kao „najstarijeg tipa ponašanja”, ${ }^{34}$ do tekstova podlistaka, koji jesu feljtonski odziv na pozive života. Po njemu je esej važan žanrovski oblik jer pomaže da se definiše nužnost izgrađivanja jednog esejističkog načina života. Tako esej ostaje pokušaj pojedinca, proza individue, način da otkrije svoju ljudsku biografiju, da ničeanski ispiše svoj ljudskobolesnički karton, da shvati kako je „činio čine sebi na uštrb, i živeo životom

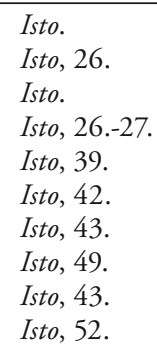


protivživotnim do krajnjih životnih granica”. ${ }^{35}$ To je poenta Ćosićevog samospoznanja, nije dosetka njegovo promišljanje da je trebalo živeti možda onako kao da nisi čovek nego samo lice iz romana, kako je Lukač i živeo. Ćosić ovo potkrepljuje citatom iz Lesingovog Laoko$n a$ : „Što više vidimo, to više moramo dodavati u mislima. Śto više dodajemo u mislima, to više moramo verovati da vidimo." ${ }^{36}$ Tako esej postaje lekovita forma.

Ćosićeva esejistička knjiga Pogled maloumnog istovremeno jeste i knjiga o eseju kao robu konteksta, kao težnji koja je unapred osuđena na neispunjenje jer se sve svodi na mnogobrojne „vidove približnosti”, neminovno dovodi autora do utopije esejizma kao zamisli o predrugojačenju. On esej sagledava kao ogled o ne-sebi, o nesebnosti, pri čemu stvaralac ne samo što ne razume pravi smisao stvarnosti, nego se još jače udaljava od nje.

Vezu sa Tomasom Manom Ćosić ostvaruje u drugom eseju knjige Pogled maloumnog. Man iz švajcarskog egzila odlazi u Beč, a Ćosić 1993. godine kreće u isti grad iz Rovinja, prvoj tački svog samoizgnanstva. Pri ruci su mu, kao uporišta, Manova dela Josif i njegova braća, te Tonio Kreger. Njihovom analizom on pokušava da dopre do sobstva, do sebstva. ${ }^{37}$ Oseća da kao što Josip postaje Egipćanin, i on postaje Rovinjez te „da bi jedino trebalo isploviti jednog jutra, $s$ mrežama i mezomarinerima i ostalim spravama, meni potpuno nerazumljivim, a da ću onde, iza Svetog Andreje, pronaći nešto što još ni usnio nisam". ${ }^{38} \mathrm{To}$, da mudrost ne štiti od ludosti, „voditeljice lutanja”, to otploviti koje srećemo i u dnevnicima Arsenija Jovanovića, u simbolici njegove Galiole, imena čamca i zaturenog pustog kvarnerskog ostrva, jeste paradigmatska crta književnosti na rubovima rata. Neko je moreplovac pa otplovi, kao Arsenije Jovanović, i lutajući Jadranom i drugim morima beži od obale i rata. Drugi se, poput Bore Ćosića, otiskuju niz pučinu eseja, spremni da sebe proglase „komentatorom pripovedanja”. U Ćosićevom dijalogu s Manom stvaralački čin postaje govor jednog mitologa drugom, dok se mit javlja kao zasnivanje života, kao bezvremena šema.

Treći odeljak - Nakrivo, neuspjelo, popišano posvećen je evropskim neurozama 20. veka. I u njemu je bitno prisutan, veliki junak tog veka, Tomas Man sa svojim delom. Ćosiću je Man poslužio kao siguran znak da je stari sistem diskretnog pripovedaštva završio svoje, da na pozornicu dolazi metod izrugivački. U tom kontekstu je Feliks Krul paradigmatski lik, njime se Ćosić ponajviše bavi u ovom poglavlju. I Lukača priziva iznova, imajući u vidu njegov otpor prema oblicima avangarde $s$ početka 20. veka. Dok piše na rubovima rata, Ćosić provlači kao zlatnu nit poruku da je ironično slaganje sa zlom oblik opiranja zlu, da je cerekanje nova faza ljudskog samoodržanja. I tu je, odista, carski žanr eseja, pomerene esejistike, u velikoj prednosti. Pomaže nam da prevrnemo literaturu od Biblije do Kanta i književnosti 20. veka, da načinimo produktivnu zbrku, u kojoj i pesnici počinju da pripovedaju o naučnim uzusima, da istraživanje postane deo stvaralačkog postupka, da i istraživači stiču zavidno stilsko i književno umeće, da sve dominantniji literarni žanr postaje Filosofija, a kad je reč o opštoj zagonetki egzistencije, esejizam postaje „kubus ljudske zapitanosti”. 


\section{LITERATURE ON THE FRINGES OF WAR. The essayist PHASE of Bora ĆOSIĆ}

In the years when the intellectual elites of the peoples of Yugoslavia began to consider taking a more defined stance towards the National Liberation War and its ideological consequences, as well the potential changes to the state and its system, certain post-war periods began to be approached with more freedom in literature. Writers turned to hybrid genres of prose, resorting to documentarity, epistolary forms, memoires, narration in the form of a dialogue ("people say...") in ways which still decidedly serve the essayist way of thinking. Those types of prose were popular and often featured in feuilletonistic writing, flourishing alongside historical novel and other types of historical fiction. The bloody breakup of Yugoslavia at the end of the 20th century contributed to the popularity of hybrid genres, namely, memoirs, diaries and essays. In that context, expatriate authors who were absent from Serbia at the time of the conflict and its immediate aftermath gained significance. As they were writing at the fringes of the war, growing ever more detached from actual events in the homeland with each passing year, their voices are distinguished by a growing uncertainty regarding their own position as the narrator. Additionally, they gradually started abandoning the beliefs and attitudes that constituted their original motives for emigration. Hybrid genres were particularly suitable for such authors, as they provided particular artistic liberties.

In the decades when "the literature of exile took its place as an important topos of human experience" (Edward Said), there emerges a literature of "exile as liberation" (Vera Linhartova), gaining importance among those writers who sought freedom of expression in self-imposed exile. Some of those writers count as the most important names of Serbian literature, such as Bora Ćosić, Mirko Kovač, Aleksandar Tišma, Vidosav Stevanović, Arsenije Jovanović, to name a few. Their work contains features which prove to be paradigmatic for literature at the turn of the 21st century and it cannot be analyzed in an appropriate manner without taking into account the prose they wrote using hybrid genres. All of them relied on the novels of Milan Kundera, who considers exile one of the crucial phenomena of the 20th century. Kundera explores the magical theme of the grand return to the homeland, mitigated by the doubt in the possibility of such a return after an absence of twenty years. In his view, the exiled person is a result of deconstruction and construction, and as such defies limitation. For Kundera, it is not merely a matter of nostalgia and the pain of contemporary exile, but also that of loss and the (in)ability to find an identity.

The essays of Bora Ćosić, written at the edges of war at the end of the 20th century form a distinct phase in his work. In his first major book of essays, entitled Pogled maloumnog, he discusses the fate of Thomas Mann as an expatriate, in the context of the novels The Magic Mountain and Joseph and His Brothers, and that of György Lukács, a thinker "in collusion with evil", who was also Mann's (fictional) protagonist. In that book, Ćosić defends the essay as a most appropriate form through which an individual can express their experience as an expatriate and justify their radical acts with regard to freedom of expression. Among his other works dealing with the subject of expatriation and the grand (non-) return, the novel Put na Aljasku (2006), the chronicle Konzul u Beogradu (2008), Doručak kod Mažestika and Jedna paralelna povest (2011) also stand out.

Keywords: totalitarianism, self-imposed exile, expatriation, esssay, literature on the edges of war, Bora Ćosić 


\section{Literatura}

Bora ĆOSIĆ, Doručak kod Majestica. Jedna paralelna povest, Beograd 2011.

Bora ĆOSIĆ, Consul u Beogradu, Beograd 2008.

Bora ĆOSIĆ, Pogled maloumnog, Zagreb 2001.

Bora ĆOSIĆ, Put na Aljasku, Beograd 2006.

Linda HUTCHEON, A Poetics of Postmodernism, New York - London 1988.

Vera LINHARTOVA, „Pour une ontologie dr l'exil” (http://www.france.czIMG/pdf).

Kate McLOUGHLIN, Authoring War. The Literary Representation of War from the Iliad to Iraq, Cambridge 2011.

Katarina V. MELIĆ, „Egzil ili veliki povratak u romanu Neznanje Milana Kundere”, Književna istorija, 44/2012., br. 147, 413.-428.

Dragan MIHOVIĆ, Rat su započeli mrtvi, Beograd 1993.

Predrag PALAVESTRA, Nekropolje, Beograd 2004.

Vladislava RIBNIKAR, „Obnova istorijskog romana: Poslednji zanosi MSS Milice Mićić Dimovske”, Književna istorija, 44/2012., br. 147, 429.-454.

Edvard SAID, „Razmišljanja o izgnanstvu”, Polja, br. 352, 28.-37. 